Forest Sector Models. Proceedings of the First North American Conference. Risto Sepälä, Clark Row and Ann Morgan (Eds.) A B Academic Berkamsted, 354 p., $1983, £ 29.50 /$ US $\$ 56.00$, ISBN 0-90736008-4.

These proceedings contain 33 papers contributed by internationally known forest econometricians and modelers at the North American Conference on Forest Sector Models, held in Williamsburg, Virginia, December 2-4,1981. It is a progress report of the Forest Sector Project of the International Institute for Applied Systems Analysis (IIASA). This project was set up as a cooperative joint effort between researchers from 15 nations to develop models of their forest sectors that can be linked together to form an international model for projecting the development of resources, the progress of industry and the flow of trade worldwide.

The papers are grouped in four sections. Part I contains a single introductory paper describing the Forest Sector Project of the IIASA. Part II contains 12 papers discussing approaches to developing forest sector models. Several features of the Timber Assessment Market Model (TAMM) and its planned improvement make it the most promising approach available for modeling the US forest sector. For other countries, however, lack of reliable data bases and government intervention in the market process may make a conventioinal econometric approach unfeasible or inappropriate, but the general principles of econometric modeling provide useful guidelines for a wide range of situations.

Part III, containing 10 papers, emphasizes some of the problems in model development, particularly in the development of 'realistic' long-term supply response estimation capabilities. Shortterm econometrics forecasts are based on the causes of changes in the past as projected into the future, while the long-term forecasts are based on long-term potentials and how technology changes can impact these potentials. Solution of the problem of how to combine the short-term structure with the long-term technology for the mid-range forecasts may be the key to 'realistic' projections and simulations.

Part IV of the proceedings consist of 10 papers covering approaches to modeling demand and international trade components. Although some of these papers might be considered as 'state-of-the-art' in terms of current knowledge of econometrics and economic models, several are extremely ambitious in their potential scope.

Owing to the nature of the proceedings, the quality, thoroughness and readibility of papers vary considerably. However, most are relatively easy to read and follow. Only one of the papers contributed was from Canada, but because of the Canadian wood supply situation, research in this area has increased considerably over he past three years. As an example, recently a team of researchers has been organized at the University of Biritsh Columbia to study Canada's forest sector with the support of the Canadian Forestry Service. By integrating models of the timber supply, product markets, and the forest industry, and incorporating the best data base available, the team expects that the whole system will enable systematic investigation of important economic and policy questions facing both governments and forest industry.

Graduate and senior students in quantitative economics will find this a valuable reference book, as may high level managers involved in long-term forestry planning and decision making. Econometricians and forest economic analysts may wish to buy their own personal copy. Despite the book's technical nature, I enjoyed reading it.

\section{Bijan Payandeh}

Great Lakes Forest Research Centre Sault Ste. Marie, Ontario

Foothills for Food and Forest. David B. Hannaway (Ed.), Oregon State University College of Agricultural Sciences, Corvallis, Symposium Series No. 2, 383 p., 1983, US\$34.95, ISBN 0-917304-00-4.

This paper-bound volume is almost as remarkable for what is absent as for what it presents. The symposium focus was ". . . interdisciplinary emphasis on production and utilization of forage and hill lands and the coordination at the grazing/forestry interface." One paper neatly recapitulated this "... The principal good to be derived from joint systems is that they efficiently and simultaneously achieve several objectives. [These] usually are 1) production of marketable wood, 2) forage and animal production, 3) establishment of shelter to improve animal survival and gain, and 4) soil maintenance and improvement."

Despite this focus there was nothing on decision-making, choosing amongst options, except mention that it must be done; one general paper on economic considerations and one site-specific paper; and there was no contribution from Africa notwithstanding the wealth of African experience with multiple-use problems. Three papers dealing with animal physiology and nutritioin seemed out-of- place in this context. Do these gaps mean we haven't really come to grips with the difficulties of land use allocation, despite the steady flow of biological study reports?

The scope of biological, as opposed to socio-economic, studies was well illustrated by the other papers. Beginning with the ecological base (1 paper), seed bed preparation (1), and fertility, nutrients and $\mathrm{N}$-fixation (4), the symposium proceeded with studies on forage production (9), harvesting of venision (1), and fee hunting (1) - an orderly sequence. The papers tended to be area-specific and dealt with present knowledge rather than whiter we are going. One stimulating exception dealt with "New frontiers in agro-forestry".

Not having seen the poster sessions I can comment only on the abstracts or brief accounts that are printed. Again there is a mixed bag, like the curate's egg - good in parts. I recall as a laddie in Scotland seeing sheep or beef cattle let into fields of turnips to feed there in early winter, and now I read that trials in Pennsylvania are finding that turnips and rape extend the fall grazing season. Goats and sheep are proving to be effective for weed control, again - this time in West Virginia. My impresison is that the poster presentations were more for exposure than to impoart information, many being preliminary accounts only.

The volume is well-presented, but in places the writing could have been improved. What does " $85 \%$ killed" really mean? What is conveyed by "Documented field examples exist in support of most objectives"?

Overall I was left feeling that here is a clear example of the perils of the "publish or perish" syndrome. Since the papers will have restricted readership, the symposium organizers might have done better to publish only brief summaries or abstracts, and poster session titles, along with contact addresses for those with specific interest or questions.

\section{R.M. Strang}

Executive Director

Forest Research Council

British Columbia 
A Time for Burning: Traditional Indian Use of Fire in the Western Canadian Boreal Forest. Henry T. Lewis, Boreal Institute for Northern Studies, University of Alberta, Edmonton, Alberta, Occas. Publ. No. 17,62 p. $1982, \$ 5.00$, ISBN 0-919058. 24-8

This is a contribution to the small, but growing, field of study dealing with aboriginal use and manipulation of fire to achieve specific vegetational changes or to perpetuate certain vegetation patterns. The publication is intended to complement the film "Fires of Spring" (not to be reviewed here), which was also sponsored by the Boreal Institute.

There are two schools of thought regarding deliberate precolonial use of fire by North American native peoples, one supposing widespread burning, the other dismissing burning as a minor activity limited to the immediate vicinity of campus or villages. Dr. Lewis, after many years of anthropological research, squarely sides with the former.

Based on extensive interviews of elderly native Indians and Metis in northern Alberta, a case is made for the use of fire having been widespread, mostly in open areas of the boreal forest, and primarily to maintain meadow or prairie. The objective for the burning activities was largely to increase the diversity of the vegetation since this was seen to improve the quality of wildlife habitat. Creating or maintaining meadows for ease of travel, improving settlement areas and campsites, improving berry patches, eliminating decadent stands, and obtaining well-cured firewood were other secondary reasons for using fire.

According to those questioned, most of the fires were set in spring when the vegetation in open areas was sufficiently dry to carry a fire while fuel moisture content in the forest was so high as to preclude fire spreading there, thus creating a natural fire barrier. Fall burning was also practised, but this was considered to be less desirable than spring burning with respect to ease of application and achievement of objectives. Summer burning was avoided because it was too difficult to control either the behaviour or effects of fire.

The hunter-gatherer is described here as an active modifier of his environment rather than an environmentally passive forager. Furthermore, Lewis claims that precolonial North Americans had a thorough understanding of boreal ecology in general and the role of fire in particular and that this understanding was essentially in accordance with contemporary theories of ecosystem strategy.

"A Time for Burning" is well written, interspersed with frequent transcripts of the interviews to make a particular point. Lewis' assertion that native use of fire fits well into the overall strategy of ecosystem development as expressed by Odum could be challenged on the basis that Odum's "postulates" have frequently been found wanting, particularly as they regard boreal forest species complexes. A recurrent theme, emphasized by the informants, states that game populations (including waterfowl) have noticeably decreased since the discontinuation of burning practices, the implication being that fire maintained high wildlife populations. No allowance is made for postcolonial industrial and agricultural habitat destruction and increased hunting pressure, making it difficult to sort out the relative contribution of any of these factors to current wildlife population dynamics.

On a minor matter, I found it distracting to flip back and forth between the body of the paper and the list of footnotes appended at the end. It would have been easier for the reader had the footnote appeared on the page it was referred to.

As a layman in the field of anthropology it would be presumptuous of me to comment on the quality of the field work. However, I cannot help recalling the ongoing acrimonious Mead/Freeman controversy regarding the relative merit or proper conduct of interviews in anthropological research.

This is recommended reading for anyone who is interested in the approach of the humanities to understanding and interpreting the role of fire in the boreal forest of Alberta.

\section{M.G. Weber}

Canadian Forestry Service

Petawawa National Forestry Institute

Chalk River, Ontario

\section{Anatomy of the Dicotyledons, 2nd ed.: Vol. II. Wood Structure and Conclusion of the General Introduction. C.R. Met-} calfe and L. Chalk, Clarendon Press, Oxford University Press, New York, 297 p., 1983, US\$75.00, ISBN 0-19-854559-2.

The second edition of Volume II was completed by C.R. Metcalfe after Dr. Chalk's death, with contributions from J. Burley, R.B. Miller, E. Chenery, J. Harborne, P.J. Peterson, Armen Takhtajan, and others. Most illustrations of wood structures were prepared at the Commonwealth Forestry Institute in Oxford, and the 3-dimension (SEM) photos were produced in New Zealand by B.G. Butterfield and B.A. Meylan. Credit is given for only a few of the excellent black and white drawings used throughout the text, e.g. illustrations of cystoliths by D.F. Cutler.

Volume I is concerned with the systematic anatomy of leaf and stem in woody dicotyledons. The present volume completes the general introduction to systematic anatomy of the vegetative organs but is more concerned with wood structure. Emphasis is laid on the great variety of modifications made by cells and tissues that can provide diagnostic clues in taxonomy.

Classification of wood, at least to genus, is necessary in order to guard against substitution and fraud: the understanding of physical characteristics is a guide to working qualities of the wood. Classification is based on differences in the various types of cells and tissues and on their distribution in the plant. Traditionally, macroscopic and microscopic features and histochemical techniques are used. For timber, identification to the generic level is generally satisfactory. This is fortunate, since at the species level wood characteristics are often ill defined and frequently overlap.

In the text, detailed descriptions of different cells and tissues such as fibres, xylem, or cambium are presented and their functions in the economy of the tree are discussed. Chapters are devoted to unusual arrangements of vascular tissue, to distinctive crystals, to anomalous and secretory structures and the families in which they occur. The occurrence of deposits of silica or calcium carbonate in plants is discussed as are woody plants that accumulate metals, such as aluminum, zinc, or magnesium. Other chapters cover the anatomy, phylogeny, and taxonomy of woods, the ecological adaptations of plants versus hereditary characteristics, chemotaxonomy as a diagnostic tool, and the application of statistics and computers to the study of wood anatomy.

The systematic arrangement of dicotyledonous families has been changed for this edition to follow Takhtajan. A chapter is devoted to the subject and there is a separate index to help readers locate families under the new arrangement.

Appendices include a subject index, an extensive bibliography plus a list of authors who contributed to the book and the first authors of papers cited, this in addition to references at the end of each chapter. Most interesting is the enlarged lists of families in which useful diagnostic characters occur, such as atypical arrangements of xylem and phloem, fibre types, cortical and medullary vascular bundles, distribution of anomalous structures, and woody plants that accumulate or secrete unusual elements. There are many cross references together with unusual lists of diagnostic aids for use in identifying wood.

This book, as might be expected from such a distinguished group of contributors, is an excellent and thoroughly researched working text for those concerned with or interested in wood anatomy. Recommended!

\section{Mary I. Moore}

Botanist

Deep River, Ontario 
Forever Green: The Story of One of Canada's Foremost Foresters. Hector Allan Richmond, Oolichan Books, Lantzville, British Columbia, 203 p. +16 p. black and white photographs, 1983, $\$ 9.95$ paperback, ISBN 0-88982-056-2.

"Forever Green" is a light, entertaining and delightful autobiography of Hector A. Richmond, an eminent Canadian forest entomologist. "Hec", as he is known to so many, reveals his remarkable ability as story teller by recounting his association with unique individuals and families, and describing his experiences with animals, during the course of carrying out forest insect surveys in remote forested areas of Canada from British Columbia in the west to Quebec in the east. Most of the 31 chapters are quite short and the writing is lively, hence the book lends itself to enjoyable relaxed reading at the end of a busy day. It can be laid aside and readily picked up again later.

Memorable tales that are recounted (not listed here in the same order as told) refer to crossing the raging Saskatchewan River with pack horses and supplies; the vagaries of Richmond's 1923 Maxwell car; Blackie, a "gypo" logger and his pet pig Pansy; goings and comings of the federal west coast survey boat the "J.M. Swaine"; predicament on a floating muskeg; the suspicious death of three-finger Slim; the Stantons of Knight Inlet; lakes of wild rice; reported dying timber that turned out to be foliage blight; wild cattle on the Queen Charlotte's; and a bear story to end all bear stories. Occasional reference is made to depredations by the mountain pine beetle and Nature's way of recovering from them. The travel advice and assistance provided by district foresters reveal the important part played by provincial forestry departments in this early era of research.

The author claims to have had no morals to convey in writing the book, yet enlightment of Nature's way pervades the work, subconsciously at first, perhaps, but more conspicuously in the final chapters. Whether planned or not this does help the layman comprehend the real difficulties associated with forest managers making public decisions on the protection of forests against forest pests such as the spruce budworm.

Several important principles of forest pest management are explained in clear and simple terms. The associated discussion, however, falters somewhat and in places lacks updating. For instance on p. 177, the author unfortunately uses the present tense in describing an earlier suspected linkage between Reye's Syndrome and budworm spray formulations, implying, incorrectly, that the question has been largely unheeded and unanswered.

To you whose work in forestry isolates you at times from family, I recommend that, once read, you offer "Forever Green" to your partner as reading material for when you are away. She will enjoy reading about "Vi", Hec's plucky wife, who made a comfortable home under canvas and acted as unpaid technician for five months as they travelled, six days a week, through the remote mountainous terrain of western Canada.

\section{Lloyd Sippell}

Research Scientist (retired)

Canadian Forestry Service

Sault Ste. Marie, Ontario

Flora of Alberta, 2nd ed. E.H. Moss, revised by John G. Packer, University of Toronto Press, Toronto, 687 p., 1983, $\$ 45.00$, ISBN 0-8020-2508-0.

The new edition of Moss's Flora of Alberta is a revision by John G. Packer, professor of biology at the University of Alberta in Edmonton. The expanded text includes a description of the area and its vegetation with notes on the major collectors. Known species have increased from 1605 to 1755 , of which 280 are introductions. Maps show the documented distribution in Alberta of native species, with their range in Canada and the United States covered in the text. As in the original flora, there are no illustrations.

The format remains essentially unchanged, with families arranged according to the Englerian system. Listing within family and genus is alphabetical. Keys have been revised or rewritten to accommodate changes where necessary, or to simplify. The well-planned index is intended as a cross reference to nomenclatural changes, with italics used for names deleted from the first edition and for synonyms helpful in consulting standard works. Chromosome numbers have been added, and established popular names are listed. There are a glossary and a limited bibliography.

To learn more about the revision, I looked in detail at several families. In keeping with the author's "pragmatic approach", the genus Oenothera has not been divided, and the ubiquitous, introduced Chrysanthemum leucanthemum retains its familiar binomial. The Saxafragaceae show few changes but three genera have been given family rank. Astragalus has gained one listing (introduced) for a total of 25 species. All of the ten new species names appeared in the first edition; seven species have been reduced to synonyms and three raised from synonymy to specific level. Draba reflects the increased range to which botanists travel. Fourteen species have been added of which two are introductions, two are name changes and ten are new alpine or northern records. In two cases, species differ mainly in chromosome number.

The book is hard-bound with a cloth cover but the layout is not well designed. The text is good, but it is difficult to pick up quickly the change from genus to species because headings are treated identically with the same size and kind of type, the same spacing, and the same marginal position. Also, many examples are noted in which a family or genus is introduced towards the bottom of a page, thus separating it from the key that follows. This is confusing. Lepidium sativum is in the text but not in the key. Pages 401-404 are missing in the volume used for review.

Dr. Packer has written for professional botanists and serious students but he hopes foresters, agriculturists, ranchers, teachers and lovers of plants in general will find the book useful. Those familiar with the original flora should soon feel at home with the revision. In spite of the reservations noted, I recommend this book.

\section{Mary I. Moore}

Botanist

Deep River, Ontario

World Trade in Forest Products. James S. Bethel (Ed.), University of Washington Press, Seattle, 551 p., 1983, US $\$ 40.00$, ISBN 0-295-96078-7.

This volume represents the proceedings of the International Symposium on World Trade in Forest Products, held at the University of Washington, March 22-25, 1983, sponsored by the University of Washington College of Forest Resources and the Geo. S. Long Fund.

In addition to a foreword and a preface the book comprises 42 papers; 33 of them were written in the United States, three in Japan, two in Canada, two by United Nations agencies, one in England, and one in the Phillipines. Although this is a comprehensive treatment of the subject on a world-wide basis, the stress is on problems facing exporters from or importers to the United States, special attention being given to the future of markets and competition for products from Washington State.

The material is treated in six parts:

I) The World's Forest Resources (six papers) deals with the problems of supply, tariffs, replenishment of growing stock, competing uses for the land resource and problems of reforestation such as investment costs and out-dated forest policies. Wood consumption will continue to rise but trade patterns are changing because of détente, rapid economic growth in some regions, the oil crisis, changing relations between major powers, currency exchange rates, resource imbalances, population growth and world debt. Many solutions for overcoming these obstacles are proposed.

II) US Opportunities in World Trade in Wood (six papers) treats separately roundwood and chips, lumber, panel products, pulp and paper, and solid wood products as affected by: traditional uses of wood in various countries; exchange rates for currencies; changing demands; trade promotion; changing technology; tariff and nontariff barriers; deficiencies in grades and standards; and establishment of credit and trade legislation.

III) The Political Climate for World Trade in Wood (eight papers) provides thoughtful discussion on environmental issues, factors affecting trade with Japan, US government steps to establish export credits, the impact of federal trade laws, antitrust considerations, protectionist atti- 
tudes, and the elimination of duties. A paper by Eugene W. Smith of Canada provides a general review of the effects of changes in US legislation on trade between Canada and the US.

IV) Governments as Wood Producers: Their Interest in World Trade (six papers) deals with proposals that the US government work with industry to improve forest productivity, access to raw materials, manufacturing capacity, availability of investment capital, and markets in increasing export opportunities from the US.

A paper by David Haley describes the role of the government of British Columbia as a wood producer and exporter and stresses the need for public involvement in the process. Other papers treat Southeast Asia as a wood producer and the highly important role the Pacific Northwest has played in supplying world markets during the last 150 years.

V) The Challenge of International Trade in Wood (10 papers) covers product mix and flow of wood materials, production problems in lumber and panel manufacturing, global increase in the use of wood, problems in trading within and with Europe, structuring trading companies, how to approach new market areas such as China, financing sales for small or medium sized firms, and the changing marketing prospects for tropical hardwoods. Several of these contain detailed data and profound analyses.

VI) Organization for World Trade (six papers) discusses need to study markets, to know importing countries' political problems, the importance of Pacific Rim countries (they consume the lion's share of the world's wood products), bank financing, and grades and specifications. One paper dealing with trade strategies outlines construction of a Global Trade Model, whereas another enumerates and evaluates the trade strategies of GATT, NATO, OECD, EEC and several bilateral alliances.

All Canadian exporters and importers will find this treatise informative and useful.

\section{D.R. Redmond}

\section{Ottawa}

Trees and Salt, Annotated Bibliography. J. Fraser, Commonwealth Agricultureal Bureaux, Farnham Royal, Slough, Buckinghamshire, England SL2 3BN, 64 p., 1983, $£ 11.85$ or US $\$ 24.90$, ISBN 0-85198-527-0.

The Commonwealth Agricultureal Bureaux (CAB) annotated bibliographies are designed to provide a comprehensive listing of literature published during a stated period on a given subject. More than 3000 bibliographies have been produced to date. Many have been prepared in response to specific requests from the "consumer", someone who wants as much information as possible, quickly, about sources of information relating to a particular topic.

What the annotated bibliography has to offer is a shortcut to sources of information on any aspect of plant science, includ- ing forestry. Such information can be obtained from a good scientific library, but the cost of ferreting it out for yourself will far exceed the cost of getting CAB to do it for you, in addition to which you will have the information in handy bookform, albeit a stapled paperback.

If, for example, you need to know about the effect of road salt on trees, then Trees and Salt is for you. This particular annotated bibliography also includes the topics of coastal salt spray and flooding (with saline water), saline soils, and laboratory studies of tolerance to salt and physiology, all in relation to trees, of course. The 228 references, which cover the period 1973 through 1982, are gleaned from the more than 8500 serial and many other publications that constitute the strength of the CAB abstracting journals (including Forestry Abstracts).

Each reference included in the annotated bibliography gives the title in full, author(s)' name, the name of the publisher and, where appropriate, the journal in which the paper is published, the date of publication, volume and issue numbers, and the page numbers, the language(s) of the paper and of any additional summaries, and the number of references cited in the paper. In short, the reader is given the full bibliographic information that appears in, say Forestry Abstracts. This, plus the annotation, enables the reader to determine whether any listed item is, to him or her, worth following up. On request, the $\mathrm{CAB}$ will generally supply, at reasonable rates, photocopies of articles of interest.

The price of bibliographies, which varies with length, may at first sight seem steep, but is not to be judged on the same basis as for books. In terms of convenience, thoroughness, and saved time, the CAB annotated bibliography represents a real bargain.

\section{R.F. Sutton}

Forestry Economics as Problem Solving. W.A. Duerr, Orange Student Bookstore, 175 Marshall Street, Syracse, N.Y. 13210, U.S.A., 1984, US\$12.95, fob Bookstore.

Students who learned the fundamentals of forestry economics from Duerr's 1960 McGraw-Hill text and were introduced to decision-making principles and cases by Duerr and his associates should welcome this book "in-progress." The latest (1982) version of the forest resource management text by Dr. Duerr and his $30 \mathrm{co}-$ authors continues to be available from the publisher, Oregon State University Bookstores, Corvallis, Oregon. Dr. Duerr started his new venture with Forestry Economics as Problem Solving in 1979 and as Professor Emeritus is pursuing it actively at Virginia Tech at Blacksburg, Virginia. Although it has already been used at several universities it continues to evolve. In its present (1984) form it offers excellent value to anyone wanting to learn more about Bill Duerr's views on forestry economics and forest resources management. The book has seven parts - a setting for forestry economics, consumers and their wants, genetic production, manufacturing production, marketing and valuation, social institutions, and summary. There are 62 chapters and a good index-glossary. Pagination is cumulative only within chapters.

The book is a useful introductory text for forestry economics. Ideas and concepts are well expressed. Examples are helpful and interesting. Although wordy in places, e.g., the chapter on consumers, the book is easy to read. There is little econometric content, much good philosophy, and no modern computer modelling. Although few Canadian references are cited, each chapter provides good access to broader views via key citations. Some new concepts are introduced and may gain acceptance. Because the living factory and its product are identical, the term "genetic identity" is coined. The pulverization principle is introduced because "in the course of economic growth, a community consumes less and less wood in the form of chunks and more and more in pulverized form." More discussion of "mainstream" economics might prove useful, e.g., externalities and production theory could be discussed more completely when introducing multiple use. Up-dating of Tables 5-2 to 5-5 from at least 1978 to 1981 is needed to reflect the changing log export situation in southeast Asia. Page 6-4 should say that New Zealand's production forests are largely man-made and reached their millionth hectare this year. Page 6-5 should note that current New Zealand policy is to rely on radiata pine and to use some specialty species such as eucalypts to complement the product mix. Page 25-5 might mention that New Zealand's second planting boom, which began in the 1960's and continues today, was largely based on private company expectations that Japan and other Asian countries will continue to buy unprocessed logs from New Zealand.

Teachers of Forestry Economics and Forest Management would find much of value in this book. It should be used at least as a supplementary reference. Forest economists and managers should welcome the background, the philosophy, and the wisdom gleaned from much study about how to solve their problems.

Kevin Todd and J. Harry G. Smith Faculty of Forestry University of British Columbia 
Trees in the 21st Century. A B Academic Publishers, Berkhamsted, Hertfordshire England HP4 2PX, 133 p., 1983, £9.75, or US\$23.50, paperback, ISBN 0-907360$01-7$.

This book constitutes the proceedings of the First International Arboricultural Conference held at the University of Sussex, Brighton, England, in August 1980. It is an arboriculturist's book that has relevance to a much wider audience, including especially foresters.

The dozen papers are a curious assortment. They address topics as diverse as: Trees in the evolution of landscapes: Effect of trees on urban climates; Urban woodlands and their recreational uses: Effects of tree roots on man-made structures; Training and education in arboriculture; Decay in trees; Planting trees for the reclamation of desert lands (summary only); Global forest cover; Brazil and its trees; and the public role in urban forestry.

The diversity is more of a strength than a weakness. Though seemingly disparate the topics are all facets of a common concern, the intertwined destinies of trees and mankind. It is highly desirable that these wider perspectives be brought into focus from time to time.

Several of the papers are excellent, being full of interesting well-documented material and penetrating comment. One or two papers would have benefitted from rigorous editing, and an index would have been useful. As a whole, however, Trees in the 21 st Century scores well in that rare class of books that are as entertaining as they are instructive.

\section{R.F. Sutton}

Scleroderris Canker of Conifers. Paul D. Manion (Ed.), Nijhoff/Junk, The Hague, 273 p., 1984, Dfl. 115.00/US\$43.00/ £28.50, ISBN 90-247-2912-2. Canada/ USA Distributor: Kluwer Boston, Inc., 190 Old Derby Street, Hingham, MA 02043, USA.

This book presents a very readable account of the general status of research on scleroderris canker through 1982. It is a compilation of the manuscripts presented at the first international symposium on scleroderris canker held in Syracuse, New York, in June of 1983. Participants at this symposium included most of the leading scientists involved in the study of this forest disease problem. Ten countries were represented.

Thirty-nine papers are included in this volume, representing a wide range of topics. The book begins with welcoming addresses by A.L. Schipper on behalf of the USDA Forest Service and by L.W. Carlson on behalf of the Canadian Forestry Service. These are followed by eight papers concerning history and current status of scleroderris canker, six of which are Canadian and one each for the United States and Europe. There are five presentations dealing with strain differences, nine on aspects of infection biology, five on disease epidemics, three on control by silvicultural measures (2) or fungicides (1), and four dealing with host resistance. Surveys using aerial photography, quarantine, and technology transfer are other topics presented. The book concludes with a brief overview, summary, and examination of future research needs. The literature cited by the authors include many recent works and will be of considerable value to those wishing to dig deeper.
This book will be of interest not only to those involved in the current research, but also to others in the forest community. Papers on history and current status, control, and quarantine are examples of presentations written for a wide audience.

The book's few faults are minor. Some of the black and white photographs added by the editor did not reproduce well, and your reviewer feels that none of them adds very much. A report of the discussion that followed the presentations at the symposium would have been interesting, though this might have delayed publication.

The book itself is fairly well constructed. The paper seems of good quality, the reproduction of the manuscripts is clear, and it is stitched rather than glued. The hard cover, however, may not wear well under hard usage such as it might receive in a library.

This book surely will be welcomed by scientists engaged in research on scleroderris canker, Gremmeniella abietina (Lagerb.) Morelet, and should find a place on the bookshelf of all forest pathologists interested in this canker problem. The price may place a personal copy of the volume out of the reach of many students to whom it would be useful as a reference work. I would also recommend this book to forest managers in areas where scleroderris canker is causing damage.

\section{D.T. Myren}

Great Lakes Forest Research Centre

Sault Ste. Marie, Ontario

\section{Change of Address}

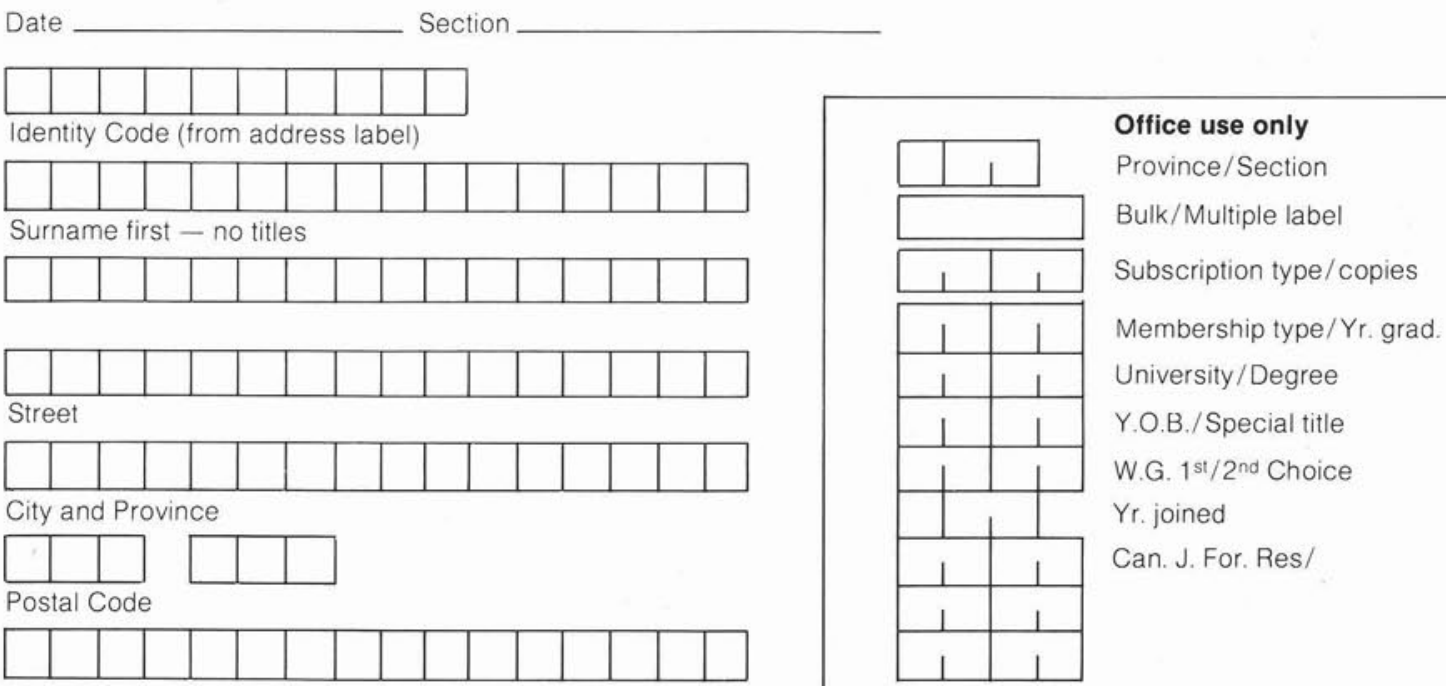

